\title{
Plasma thyrocalcitonin and parathyroid hormone concentrations in early neonatal hypocalcaemia
}

\author{
C ROMAGNOLI, E ZECCA, G TORTOROLO, A DIODATO, G FAZZINI, AND \\ M SORCINI-CARTA
}

Divisione Neonatologica, Università Cattolica del Sacro Cuore e Laboratorio di Metabolismo e Biochimica Patologica, Istituto Superiore di Sanità, Rome, Italy

SUMmaRY During the first week of life serum calcium, phosphorus, magnesium, immunoreactive thyrocalicitonin hormone, and parathyroid hormone concentrations were determined daily in 36 preterm and 29 small for gestational age, full term, healthy infants. Preterm babies with early neonatal hypocalcaemia had significantly higher concentrations of serum thyrocalcitonin hormone in the first four days of life than normocalcaemic preterm babies. Parathyroid hormone concentrations were similar in hypocalcaemic and normocalcaemic infants. In contrast, in the full term group no significant differences were detected in thyrocalcitonin hormone and parathyroid hormone patterns between hypocalcaemic and normocalcaemic subjects. This suggests two different pathogeneses for early hypocalcaemia in low birthweight infants. Hyperthyrocalcitoninaemia seems to be the main determining factor in preterm infants, while a non-hormonal pathogenesis should be considered in full term infants who are small for gestational age.

Hypocalcaemia occurs often in the neonatal period, mainly in preterm and small for gestational age, full term babies. ${ }^{1-3}$ Late hypocalcaemia, which occurs after the third day of life, is associated with high phosphorus:calcium ratios in formula feeds and, more rarely, with hypomagnesaemia or hormonal disorders. $^{24-6}$ The pathogenesis of early hypocalcaemia, which occurs during the first 72 hours of life, has not been clearly defined, ${ }^{78}$ although inadequate secretion of parathyroid hormone $e^{8-11}$ and increased concentrations of thyrocalcitonin hormone ${ }^{91213}$ have been implicated. Until now, however, the different secretions of these hormones in the neonatal period has merely been related to the mean total serum calcium concentrations, without subdividing the studied population into those with and without hypocalcaemia.

The aim of the present study was to investigate the role of thyrocalcitonin and parathyroid hormones in the pathogenesis of early neonatal hypocalcaemia in hypocalcaemic and normocalcaemic babies who were either preterm or small for gestational age and full term.

\section{Patients and methods}

The study was carried out on 65 healthy low birthweight newborn babies (birth weight $<2500 \mathrm{~g}$ ) who were preterm $(n=36)$ or full term $(n=29)$. It was approved by the ethical committee of our department and had the informed consent of the parents. Gestational age was assessed according to the last normal menstrual period and confirmed by the Dubowitz scoring system. ${ }^{14}$ Infants who were small for gestational age were defined according to the standards of Lubchenco et al. ${ }^{15}$ All babies were nursed in incubators at normal temperature and fed the same standard formula within the first hour of life. Energy and fluid intakes per $\mathrm{kg}$ and per day were similar for all subjects throughout the study. No drugs or vitamin supplements were given during the study. Phototherapy was started when serum total bilirubin concentrations reached $205 \mu \mathrm{mol} / \mathrm{l}$. Serum calcium, phosphorus, magnesium, thyrocalcitonin hormone, and parathyroid hormone concentrations, acid base state, packed cell volume, and haemoglobin, total bilirubin, glucose, and proteins concentrations were determined daily on capillary or central blood samples during the first week of life. Serum total calcium was determined by Eppendorf flame spectrophotometry, ${ }^{16}$ and inorganic phosphorus $^{17}$ and magnesium ${ }^{18}$ by a colorimetric method. Serum thyrocalcitonin and parathyroid hormones were determined by radioimmunoassay 
(RIA): the RIA-mat Calcitonin II method measures thyrocalcitonin hormone values between 10 and $1000 \mathrm{pg} / \mathrm{ml}$ and the RIA-mat PTH method measures directly serum parathyroid hormone 1-84 equivalents from 15 to $1000 \mathrm{pmol} / \mathrm{l}$ in human serum (BykMallinckrodt).

Hypocalcaemia was defined as a total serum calcium concentration less than $1.75 \mathrm{mmol} / \mathrm{l}$ in the first 72 hours of life. We compared serum calcium and thyrocalcitonin and parathyroid hormone concentrations firstly in preterm babies with small for gestational age full term babies and secondly in all babies who were hypocalcaemic with those who
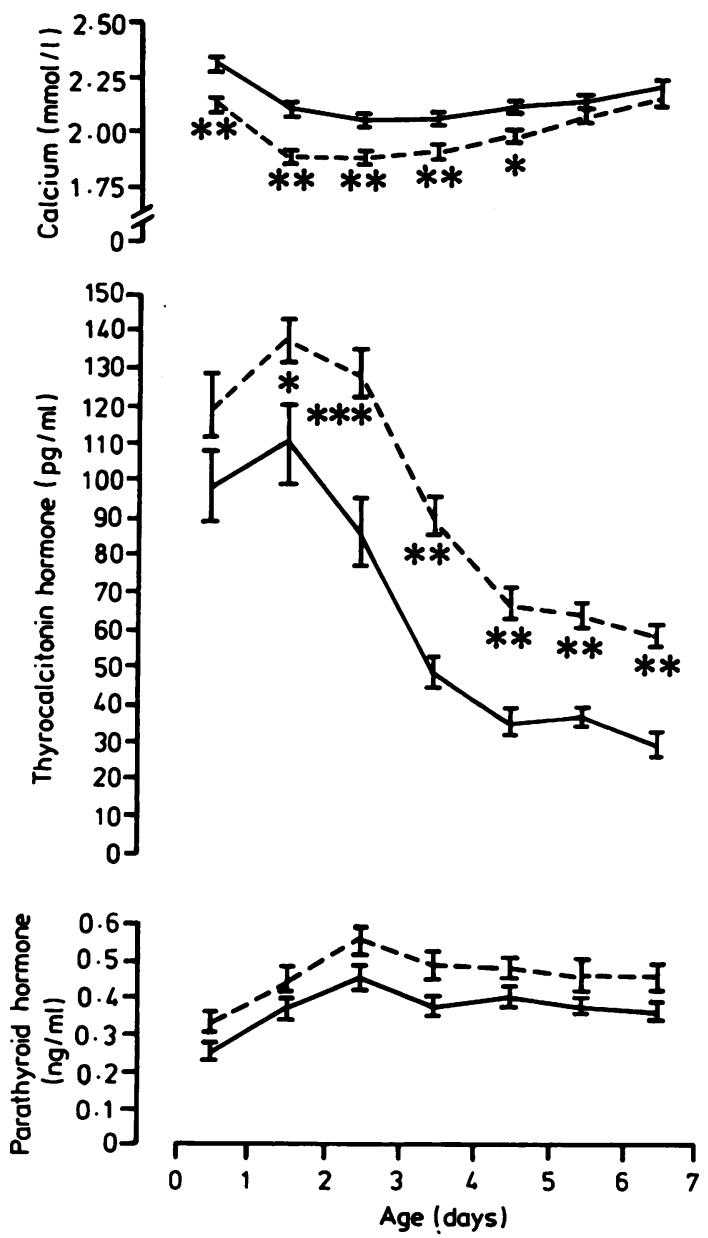

Fig. 1 Serum calcium, parathyroid hormone, and thyrocalcitonin hormone concentrations in preterm (-) and small for gestational age, full term (- - ) babies during the first week of life.

${ }^{*} \mathrm{p}<\left(0 \cdot 05 ;{ }^{* *} \mathrm{p}<0 .\left(01 ;{ }^{* * *} \mathrm{p}<(0) \cdot(0) 1\right.\right.$. were normocalcaemic. All results are expressed as mean (SD).

Statistical analysis was performed by the two tailed Student's $t$ test and the correlation coefficient.

\section{Results}

Preterm babies $v$ small for gestational age, full term babies. The mean serum calcium and thyrocalcitonin and parathyroid hormone concentrations in preterm and small for gestational age, full term babies during the first week of life are shown in Figure 1 and clinical data on these study groups in Table 1. Mean serum calcium concentrations were significantly lower and mean serum thyrocalcitonin hormone concentrations significantly higher in preterm babies compared with small for gestational age, full term babies. No significant differences were detected in parathyroid hormone concentrations between the two groups.

An inverse correlation was found in both the preterm and the full term babies between serum thyrocalcitonin hormone and calcium and between serum parathyroid hormone and calcium in the first three days of life. The correlation coefficient for thyrocalcitonin hormone and calcium concentrations was $r=0.993$ on day $1, r=0.995$ on day 2 , and $r=0.983$ on day $3(p<0.01)$ and for parathyroid hormone and calcium concentrations was $r=0.828$ on day $1, r=0.839$ on day 2 , and $r=0.847$ on diy 3 $(\mathrm{p}<0 \cdot 02)$.

\section{Hypocalcaemic $v$ normocalcaemic babies. \\ Preterm babies}

The incidence of early hypocalcaemia was $33 \cdot 3 \%$ (12 of 36 ) in the preterm babies and $17 \cdot 1 \%$ (five of 29 ) in the full term babies. Mean concentrations of serum calcium and thyrocalcitonin and parathyroid hormones in hypocalcaemic and normocalcaemic preterm babies during the first week of life are shown in Figure 2 and clinical data on these study groups in Table 2. Serum calcium decreased after

Table 1 Clinical data of the study groups. Values are No or mean $(S D)$

\begin{tabular}{lcc}
\hline & Study group & \\
\cline { 2 - 3 } & Preterm infants & $\begin{array}{l}\text { Simall for } \\
\text { gestational age. } \\
\text { full term infants }\end{array}$ \\
\hline (n) & $(36)$ & $(29)$ \\
Sex (M:F) & $14: 22$ & $12: 17$ \\
Birth weight (g) & $2(133(39(3)$ & $2250(184)$ \\
Gestational age (wks) & $34 \cdot 1(1.6)$ & $38.1(1.1)$ \\
\hline
\end{tabular}


the first day of life in both groups, more markedly so in the hypocalcaemic group. The lowest postnatal value in the hypocalcaemic group was $1.7 \mathrm{mmol} / \mathrm{l}$ on the second and third days of life and in the normocalcaemic group was $2.0 \mathrm{mmol} / \mathrm{l}$ on the third
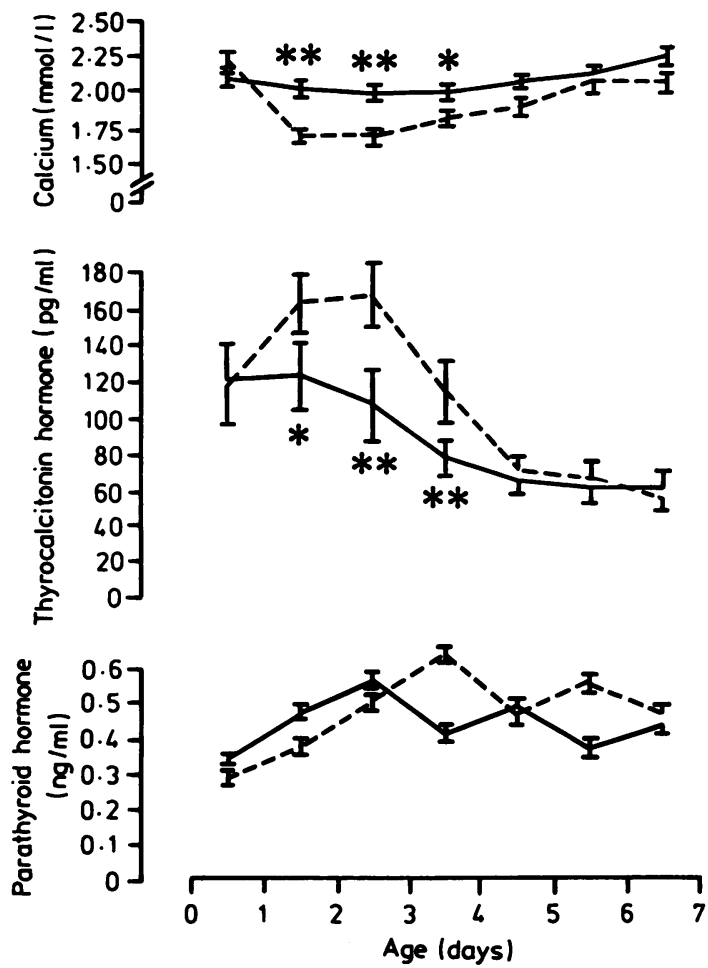

Fig. 2 Serum calcium, parathyroid hormone, and thyrocalcitonin hormone concentrations in hypocalcaemic (- - -) and normocalcaemic (-) preterm babies during the first week of life.

${ }^{*} \mathrm{p}<0.01 ;{ }^{* *} \mathrm{p}<0.001$.

Table 2 Clinical data of hypocalcaemic and normocalcaemic patients within the preterm and small for gestational age, full term study groups. Values are No or mean $(S D)$

\begin{tabular}{lcc}
\hline & $\begin{array}{l}\text { Hypocalcaemic } \\
\text { patients }\end{array}$ & $\begin{array}{l}\text { Normocalcaemic } \\
\text { patients }\end{array}$ \\
\hline $\begin{array}{l}\text { Preterm babies } \\
\text { (n) }\end{array}$ & $(12)$ & $(24)$ \\
Sex (M:F) & $6: 6$ & $8: 16$ \\
Birth weight (g) & $2150(310)$ & $1975(430)$ \\
Gestational age (wks) & $34 \cdot 1(1 \cdot 5)$ & $34 \cdot 1(1 \cdot 7)$ \\
Full term babies & & $(24)$ \\
(n) & $(5)$ & $9: 15$ \\
Sex (M:F) & $3: 2$ & $2260(180)$ \\
Birth weight (g) & $2237(204)$ & $38 \cdot 2(1 \cdot 2)$ \\
Gestational age (wks) & $37 \cdot 9(1 \cdot 0)$ & \\
\hline
\end{tabular}

day of life. Significant differences in calcium concentrations were observed between the two groups on the second, third, and fourth days of life $(p<0.001$, $\mathrm{p}<0.001$, and $\mathrm{p}<0.01$, respectively). Mean thyrocalcitonin hormone concentrations were similar on the first day of life in the two groups. A pronounced increase in the mean serum thyrocalcitonin hormone concentration from $118 \mathrm{pg} / \mathrm{ml}$ to $169 \mathrm{pg} / \mathrm{ml}$ on the third day, was observed in the hypocalcaemic babies. Thyrocalcitonin hormone values in hypocalcaemic babies were significantly higher than in normocalcaemic infants on the second, third, and fourth days of life $(p<0.01, p<0 \cdot 001$, and $p<0.001$, respectively). Thereafter, similar thyrocalcitonin hormone concentrations were observed in both preterm groups. In both groups an increase in serum parathyroid hormone concentrations, more evident in hypocalcaemic $(+113 \%)$ than in normocalcaemic $(+62 \cdot 8 \%)$ babies, was observed at between one and three days of life, followed by constant concentrations up to the seventh day. No significant differences in parathyroid hormone values and patterns between hypocalcaemic and normocalcaemic preterm infants were observed. Serum phosphorus, magnesium, total protein, and electrolyte concentrations, packed cell volume, and acid base state were similar in both preterm groups. No infant had a serum glucose concentration lower than $2.22 \mathrm{mmol} / \mathrm{l}$ and only 25 babies ( 12 of whom were hypocalcaemic and 13 of whom were normocalcaemic) were treated with phototherapy.

\section{Small for gestational age, full term babies}

Figure 3 shows the mean serum calcium and thyrocalcitonin and parathyroid hormone concentrations for the hypocalcaemic and normocalcaemic small for gestational age, full term babies. The serum calcium concentration decreased in the hypocalcaemic group from the initial mean value of $2 \cdot 2$ $\mathrm{mmol} / \mathrm{l}$ to $1.72 \mathrm{mmol} / \mathrm{l}$ on the third day of life; the lowest mean serum calcium concentration in the normocalcaemic group was $2 \cdot 12 \mathrm{mmol} / \mathrm{l}$ on the fourth day of life. Thyrocalcitonin hormone concentrations showed a small increase in the first 24 hours and then decreased in both groups. A similar increase of serum parathyroid hormone values was observed in hypocalcaemic $(+56 \%)$ and normocalcaemic $(+74 \%)$ babies between one and three days. No particular trends of parathyroid hormone were then observed in either group. Although significant differences in mean serum calcium concentrations were observed between the two groups on the second, third, and fourth days of life $(p<0 \cdot 01$, $p<0.001$, and $p<0.01$, respectively), no significant differences were detected in mean serum thyrocalcitonin and parathyroid hormone concentrations 

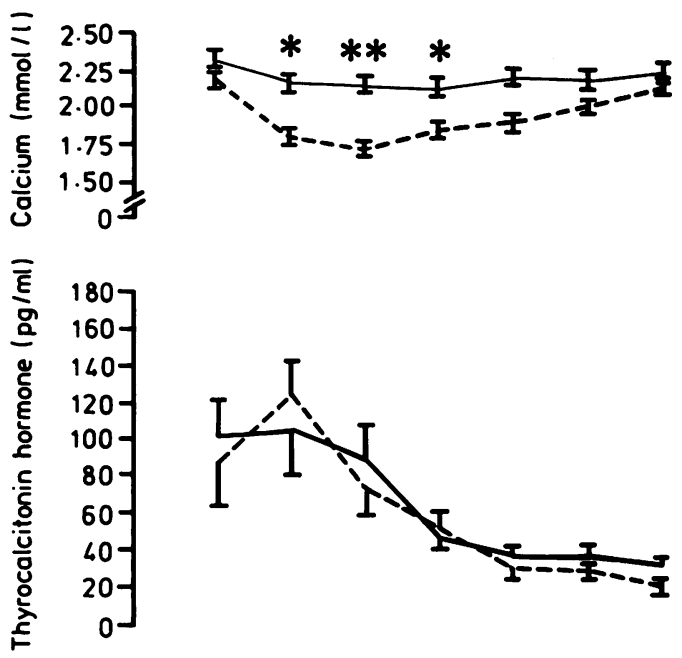

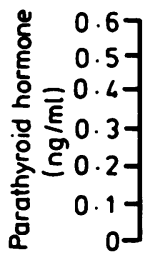

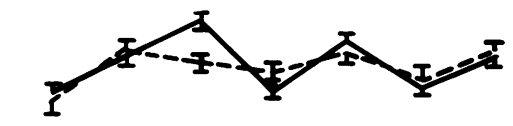

0

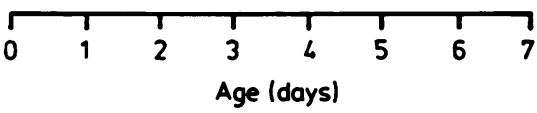

Fig. 3 Serum calcium, parathyroid hormone, and thyrocalcitonin hormone concentrations in hypocalcaemic (- - ) and normocalcaemic (-) small for gestational age, full term babies during the first week of life.

${ }^{*} \mathrm{p}<0.01 ;{ }^{* *} \mathrm{p}<0.001$.

during the study. Serum phosphorus, magnesium, total protein, and electrolyte concentrations, packed cell volume, and acid base state were similar in hypocalcaemic and normocalcaemic small for gestational age, full term infants. No full term infant had a serum glucose concentration lower than 2.22 $\mathrm{mmol} / \mathrm{l}$ and 11 babies (five of whom were hypocalcaemic and six of whom were normocalcaemic) were treated with phototherapy.

No hypocalcaemic preterm or small for gestational age, full term infants had any important clinical symptoms. All those with hypocalcaemia recovered spontaneously, except for two (one preterm baby and one full term baby), whose early hypocalcaemia was followed by late hypocalcaemia, which was treated orally with vitamin D and $10 \%$ calcium gluconate solution.

\section{Discussion}

Our results indicate that the increase in thyrocalcitonin hormone concentrations observed in preterm and small for gestational, full term babies in the first 24 hours of life is associated with a fall in serum calcium concentrations, in spite of rising parathyroid hormone concentrations. Preterm babies had significantly higher thyrocalcitonin hormone concentrations and significantly lower calcium concentrations compared with the small for gestational age, full term infants during the whole of the first week of life. Moreover, our study confirmed the higher incidence of early hypocalcaemia in the preterm compared with the full term babies, as previously reported. ${ }^{58}$

One possible cause of early hypocalcaemia is a transient state of neonatal hypoparathyroidism, secondary to fetal hypercalcaemia. ${ }^{8}$ Yet in our study no significant differences in parathyroid hormone values were observed between hypocalcaemic and normocalcaemic preterm and small for gestational age, full term infants. On the contrary, our finding of a rapid postnatal increase in parathyroid hormone strongly suggests, as previously reported, ${ }^{12}$ an effective response of parathyroid glands to falling serum calcium concentrations, gestational age not being a conditioning factor for this response.

The physiological role of thyrocalcitonin hormone in the regulation of neonatal calcium metabolism remains to be clarified. High thyrocalcitonin hormone concentrations in cord blood, ${ }^{12}$ as well as a rise in the concentrations of this hormone during the first hours of life,,$^{10} 13$ possibly influence the fall in serum calcium concentrations during the neonatal period. The significant differences we found in serum thyrocalcitonin hormone concentrations between hypocalcaemic and normocalcaemic preterm babies during the first three days of life support this hypothesis. In contrast, the observation that hypocalcaemic and normocalcaemic small for gestational age, full term infants showed similar trends in thyrocalcitonin hormone concentrations during the study suggests a non-hormonal pathogenesis of the early hypocalcaemia in these babies. The interruption of the transplacental calcium transfer is probably more important in this group of babies.

As it has been shown that defective vitamin D metabolism is not a primary factor in the pathogenesis of early neonatal hypocalcaemia,${ }^{11}$ and also that vitamin D supplementation fails to prevent early neonatal hypocalcaemia in premature infants, ${ }^{20}$ vitamin $\mathrm{D}$ and its active metabolites were not measured in this study.

Our study suggests a different pathogenesis for early hypocalcaemia in preterm babies and small for 
gestational age, full term babies. A higher and longer secretion of thyrocalcitonin hormone is the main determining factor of early hypocalcaemia in preterm babies, while a non-hormonal cause should be considered for early hypocalcaemia in small for gestational age, full term infants. It is not clear why only some preterm babies have hyperthyrocalcitoninaemia during the early neonatal period. A relation between mode of delivery and thyrocalcitonin hormone concentrations during the first hours of life has been reported (Bagnoli F, De Leo V, Bruchi S, Buonocore G, Berni S, Talluri B, Bracci R. Calcitonin, parathyroid hormone and prolactin concentrations in the first days of life in relation to the mode of delivery; presented at the International symposium on the endocrine physiology of pregnancy and peripartum period. Sien, April 1984). Our data did not show this relation in either premature or full term infants.

\section{References}

1 Bergman L. Plasma calcium fraction during the first days of life with special reference to neonatal hypocalcemia. Biol Neon 1972:20:346-59.

2 Root A, Harrison H. Recent advances in calcium metabolism. II. Disorders of calcium homeostasis. J Pediatr 1976;88:177-99.

${ }^{3}$ Tsang R. Donovan I, Steichen I. Calcium physiology and pathology in the neonate. Pediatr Clin North Am 1976;23: 611-26.

+ David L. Salle B. Physiopathologie de l'hypocalcemie neonatalc. Arch Fr Pediatr 1980;37:215-8.

5 Romagnoli C, Pesaresi MA, Currò V. DeTurris P. Zecca E, Tortorolo G. Possible pathogenetic factors in hypocalcemia of low birth weight newborn infants. Ped Med Chir 1981;3: 171-6.

" Tsang R. Oh W. Neonatal hypocalcemia in low birth weight infants. Pediatrics 1970;45:773-81.

7 Rosli A. Fanconi A. Neonatal hypocalcemia: "carly type" in low birth weight newborns. Helv Paediatr Acta 1973:28:443-57.

* Tsang R, Light I, Sutherland J, Klcinman L. Possible pathogenetic factors in neonatal hypocalcemia of prematurity: the rolc of gestation, hyperphosphatemia, hypomagnesiemia, urinary calcium loss and parathormone responsiveness. $J$ Pediatr 1973;82:423-9.

9 Hillman L, Rojanasathit S, Slatopolsky E, Haddad J. Serial measurements of serum calcium, magnesium, parathyroid hormone, calcitonin and 25-hydroxy-vitamin D in premature and term infants during the first week of life. Pediatr Res 1977:11:739-44.

10 Salle B, David L, Chopard J, Grafmeyer D, Renaud H. Prevention of early hypocalcemia in LBW infants with continuous calcium infusion: effect on serum calcium, phosphorus, magnesium and circulating immunoreactive parathyroid hormone and calcitonin. Pediatr Res 1977;11:1180-6.

1 Salle B, David L. Glorieux F, Delvin E, Senterre J, Renaud H. Early oral administration of vitamin D and its metabolites in premature neonates. Effect on mineral homeostasis. Pediatr Res 1982;16:75-8.

12 David L. Salle B, Putet G. Grafmeyer D. Serum immunoreactive calcitonin in low birth weight infants. Description of early changes in serum calcium, phosphorus, magnesium, parathyroid hormone and gastrin levels. Pediatr Res 1981;15:803-8.

13 Sann L. David L. Chayvialle J, Lasne Y, Bethenod M. Effect of early oral calcium supplementation on serum calcium and immunoreactive calcitonin concentration in preterm infants. Arch Dis Child 1980;55:611-6.

14 Dubowitz L, Dubowitz V, Goldberg C. Clinical assessment of gestational age in the newborn infants. $J$ Pediatr 1970;77:1-10.

15 Lubchenco L. Hansman C, Dressler M, Boyd E. Intrauterine growth as estimated from liveborn birth weight data at 24 to 42 weeks of gestation. J Pediatr 1962;32:793-800.

in Goldstein D, Stark-Mayer C. New specific test for calcium. Anal Chim Acta 1958;19:437-9.

17 Zilversmit DB. Microdetermination of plasma phospholipids by trichloroacetic acid precipitation. J Lab Clin Med 1950;35: 155-60.

18 Mann CK, Yoe JK. Spectrophotometric determination of magnesium with sodium 1-azo-2-hydroxy-3-(2, 4-dimethyl carboxanilido)-naphtholene-1' -(2-hydroxybenzene-5-sulforate). Anal Chem 1956;28:202-5.

20) Zecca E, Romagnoli C, De Carolis MP, Tortorolo G. Il calcifediolo nella profilassi dell'ipocalcemia del neonato di basso peso. Aggiornamento Pediatrio 1983;34:261-4.

Correspondence to Professor C Romagnoli, Divisione di Neonatologia, Universita Cattalica S Cuore, Largo A Gemelli, 8-(00168 Roma. Italy.

Received 17 December 1986 